\title{
Mode of Birth and Development of Maternal Postnatal Post-Traumatic Stress Disorder: A Mixed Methods Systematic Review and Meta-Analysis
}

\author{
Jemima Carter ${ }^{1}$, Debra Bick ${ }^{2}$, Daniel Gallacher ${ }^{2}$, and Yan-Shing Chang ${ }^{3}$ \\ ${ }^{1}$ King's College London Faculty of Life Sciences and Medicine \\ ${ }^{2}$ University of Warwick \\ ${ }^{3}$ King's College London
}

July 3, 2020

\begin{abstract}
Background: Post-traumatic stress disorder (PTSD) affects approximately $3 \%$ of women in the postnatal period, but less is known about risk factors for PTSD than for other postnatal mental illnesses. Objectives: To analyse literature surrounding the impact of mode of birth on postnatal PTSD. Search Strategy: Five databases were systematically searched (1990-2019). Selection Criteria: Studies investigating the link between mode of birth and postnatal PTSD in high income countries. Data Collection and Analysis: Quantitative and qualitative data were collected and synthesised. Meta-analysis was performed with four of the studies, and the rest were analysed narratively. Main Results: Twelve quantitative and two qualitative studies were included in the review. Most found a significant relationship between mode of birth and maternal PTSD symptoms. Meta-analysis found caesarean section was more associated with PTSD than vaginal delivery (VD) ( $=0.005$ ), emergency caesarean section (EmCS) more than elective caesarean section (ElCS) $(\mathrm{p}<0.001)$, instrumental vaginal delivery (IVD) more than spontaneous vaginal delivery $(\mathrm{SVD})(\mathrm{p}<0.001)$ and EmCS more than VD $(\mathrm{P}<0.001)$. Women who developed PTSD after EmCS felt less in control and less supported than those who did not develop it after the same procedure. Request for repeat ElCS appeared more common among women with pre-existing postnatal PTSD, but this may subsequently leave them feeling dissatisfied and their fears of childbirth unresolved. Conclusions: Modes of birth involving emergency intervention may be risk factors for the development of postnatal PTSD. Ensuring that women feel supported and in control during emergency obstetric interventions may mediate against this risk.
\end{abstract}

\section{Introduction}

Post-Traumatic Stress Disorder (PTSD) is a psychiatric condition whereby individuals suffer flashbacks, anxiety and avoidance following exposure to a traumatic event. Given that childbirth is usually a positive and life-affirming event, only recently did the scientific community begin to recognise that giving birth could be deeply traumatic for some women. In 1997 the phenomenon was recognised widely enough that the first large-scale study was carried out by a group in Sweden, which found that $1.6 \%$ of postnatal women studied showed symptoms of PTSD. A recent meta-analysis of 78 studies found the prevalence of postnatal PTSD to be higher, at $3.1 \%$ in the community and $15.7 \%$ in at-risk populations . Risk factors for postnatal PTSD may include nulliparity, increased anxiety, feeling out of control and lack of social support. Another risk factor is the impact of mode of birth, in particular caesarean section (CS) .

Given the global increase in the proportion of women who deliver via CS, an association between this mode of birth and postnatal PTSD could have wide implications. This review is the first to analyse the impact of mode of birth on maternal postnatal PTSD. The review aimed to investigate whether onset of PTSD in the postnatal period is more common following CS or other modes of birth, to raise awareness of the risks of 
developing PTSD and encourage better recognition and treatment of the condition. Three primary and four secondary review questions were developed. For the purposes of the review, modes of birth were categorised into elective caesarean section (ElCS), emergency caesarean section (EmCS), spontaneous vaginal delivery (SVD) and instrumental vaginal delivery (IVD). IVD was classified as the use of forceps and/or vacuum extraction (ventouse) .

\section{PRIMARY REVIEW QUESTIONS:}

- Are women who have a CS more likely to experience PTSD postnatally than women who have a VD?

- What are the views of women who have postnatal PTSD on the impact of birth mode on their PTSD?

- What are the views of those who support women (i.e. family, peer support groups, midwives and other healthcare staff) on the impact of birth mode on development of PTSD?

\section{SECONDARY REVIEW QUESTIONS:}

- Is an EmCS more likely to trigger symptoms and signs of PTSD than an ElCS?

- Is an IVD more likely to trigger symptoms and signs of PTSD than a SVD?

- Does a previous history of postnatal PTSD impact on a woman's decision-making about her mode of birth in subsequent pregnancies?

- How do women who have PTSD perceive the impact of social/peer support on their mental health outcomes?

\section{Methods}

\section{ELIGIBILITY CRITERIA}

This review included both quantitative and qualitative studies to give a holistic overview of the literature. Studies from 1990 onwards were included, as research into PTSD following childbirth first started in this decade. This review included studies which explored PTSD in women who gave birth by different modes of birth as described in the introduction.

For quantitative research, studies were included if participants included women who had given birth within 6 months prior to recruitment to a live singleton infant carried to term in high-income countries as classified by the World Bank . Qualitative studies were included if participants were either postnatal women who met the criteria as above, or people who supported these women. This category included husbands or partners, friends, family, peers, support groups and healthcare providers.

\section{SEARCH STRATEGY}

The protocol for this review was registered on the PROSPERO International Prospective Register of Systematic Reviews (CRD42018089132). Searches were conducted in CINAHL, the Cochrane Library, MEDLINE, PsycINFO and Scopus on the $20^{\text {th }}$ March 2018, and an update search was performed on the $25^{\text {th }}$ October 2019. There were two searches run in each database: one for quantitative studies and one for qualitative studies. Reference searching was performed in relevant reviews identified by the searches. Full search strategies can be seen in appendices S1-S2 .

\section{STUDY SELECTION AND DATA EXTRACTION}

Abstract screening was undertaken, followed by full-text assessment by JC and Y-SC. Papers which met eligibility criteria were included. If a paper did not explicitly state these criteria, authors were contacted via email.

A data extraction form was created for quantitative and qualitative studies. From quantitative studies, the data extracted included incidence of postnatal PTSD for women who underwent different modes of birth in the form of Odds Ratios comparing the mode of birth studied with SVD where possible. For the qualitative studies, key findings (i.e. themes) were extracted.

QUALITY APPRAISAL 
Quality was assessed by JC and Y-SC using the Newcastle-Ottawa Scale (NOS) for quantitative cohort studies, the Centre for Evidence Based Medicine (CEBM) Critical Appraisal Checklist for cross-sectional studies and the Critical Appraisal Skills Programme (CASP) tool for qualitative studies.

\section{OUTCOME MEASURES}

\section{Primary outcomes}

The primary outcome of interest was PTSD in the postnatal period, defined as the six months following giving birth. The diagnosis of PTSD should have been based on DSM criteria, using either the Impact of Event Scale (IES) or another validated scale used by study authors. Data on symptoms of PTSD which did not meet full criteria for a diagnosis of PTSD were also included, as not all women participating in the studies selected had undergone a full diagnostic interview. Qualitative data were included which described the attitudes and experiences towards different modes of birth by women who developed postnatal PTSD and those who supported them.

\section{Secondary outcomes}

Secondary outcomes included the impact of a history of postnatal PTSD on subsequent birth-planning. Research indicates that women who experienced a traumatic birth are more likely to request an elective caesarean section, so studies investigating this relationship were also evaluated. Another secondary outcome was how women with postnatal PTSD perceived the impact of social support on their mental health outcomes.

\section{DATA ANALYSIS}

The data from the quantitative studies were assessed for suitability in a meta-analysis. Studies were included if they reported a sample size, a mean PTSD score and standard deviation at a relevant follow-up point. Meta-analyses were conducted to explore the effect of mode of birth on the score of PTSD symptoms. Due to the range of scales used, it was necessary to convert each to standardised mean difference (SMD) using Hedge's $\mathrm{g}$ as implemented in the Stata network suite of commands. When the reporting of subgroups differed, pooling was performed in line with recommendations from the Cochrane handbook . Results were interpreted using Cohen's guidelines for interpretation of SMD magnitude : 0.2 a small difference, 0.5 a medium difference and 0.8 a large difference. Fixed effects models were used due to the small number of studies. Estimates were produced from both meta-analyses (considering only studies with directly relevant data) and network meta-analyses (which includes information from indirect comparisons when estimating the effect of interest). Heterogeneity was assessed through a comparison of the study characteristics. $\mathrm{I}^{2}$ could not be calculated.

Qualitative studies and quantitative studies not suitable for statistical analysis were reported narratively.

\section{Results}

\section{SEARCH RESULTS}

The systematic search on 20/03/18 retrieved 602 quantitative studies from the five databases, and an additional seven studies from reference searching of appropriate reviews identified by the search (Figure 1). After deduplication, 431 records remained for abstract screening. Of these, full text screening was carried out on 68 , following which 11 quantitative studies were included (Table 1). The updated search on 25/10/19 retrieved one more relevant quantitative study (Table 1). The qualitative search on 20/03/18 retrieved 73 studies from the five databases. 17 qualitative studies were found in the quantitative search process and these added to the qualitative group (Figure 2) . After deduplication, 70 records remained for abstract screening. Full text analysis was performed on seven studies, of which two met the inclusion criteria (Table 2) . The updated search on 25/10/19 retrieved no new appropriate qualitative studies.

\section{STUDY CHARACTERISTICS}

The 12 quantitative studies were all observational; 10 were cohort and two were cross-sectional. Both qualitative studies presented findings from interviews. In the quantitative group, sample size ranged from 42 
to 1842 , with a mean of 464 participants. Sample sizes in the qualitative studies were much smaller, ranging from eight to 84. Three quantitative studies were conducted in Canada, two in England, two in Israel, two in Sweden, one in Australia, one in Germany and one in the USA. Both of the qualitative studies were from Sweden. Recruitment of participants for the studies was mostly through either community midwifery services or maternity wards in hospital, but one recruited participants through the internet and via maternity services and one recruited specialist midwives at clinics for postnatal PTSD .

While the qualitative studies used semi-structured interviews to collect data about the experiences of women with postnatal PTSD and those who supported them, the quantitative studies all used diagnostic tools to examine the prevalence of PTSD amongst their participants. Several diagnostic tools were used, with the most commonly used scales including the Post-traumatic Stress Diagnostic Scale, used by three studies and the Impact of Event Scale, also used in three studies .

\section{QUALITY ASSESSMENT}

The quality of the quantitative cohort studies was assessed using the NOS, which found all 10 of the cohort studies had a medium risk of bias. The cross-sectional studies were assessed using the CEBM checklist. One scored six out of a possible 12 desirable answers and the other scored five, indicating the studies may not be of high quality. The qualitative studies were assessed using the relevant CASP checklist . Both achieved a score of at least 8 out of 10, showing the studies were of good quality. Full quality assessments can be seen in

Table S1, S2 and S3.

\section{DESCRIPTION OF FINDINGS}

\section{Mode of birth and PTSD}

Due to the variation in study methodology and outcome measures, it was not possible to perform metaanalysis across all studies for all of the review questions. Categorisation of mode of birth varied considerably. Mode of birth also tended to be a secondary outcome in studies, and rather than reporting individual statistics, many studies simply performed an analysis of variance for all modes of birth.

For this reason, the only comparison possible across all studies was whether mode of birth was significantly associated with symptoms of PTSD. Overall, eight of the studies found significant variance in symptoms of PTSD across the modes of birth they investigated . The remaining four studies did not find a significant association between mode of birth and PTSD .

\section{Caesarean Section versus Vaginal Delivery}

Meta-analysis of three studies showed that women who experienced a CS had a slightly higher PTSD symptom score than women who had a $\operatorname{VD}$ (Figure 3). This difference (Effect size $=0.17$ ) was below that of the threshold to be considered small, however it was statistically significant at the 0.05 threshold $(\mathrm{p}=0.005)$. This may be a smaller effect size (ES) than expected, because this analysis pooled SVD and IVD, and also pooled ElCS and EmCS. Both poolings likely contain distinct groups which may have varying effects on PTSD.

\section{Emergency caesarean section}

Emergency caesarean section is considered to be the most traumatic mode of birth, probably due to the urgency and stress associated with needing emergency surgery, usually when a woman is in established labour. Six of the studies in the quantitative search found EmCS to be associated with an increased proportion of women showing symptoms of PTSD .

Meta-analysis of three studies comparing EmCS to SVD suggested a medium difference (ES=0.64) of PTSD symptoms between these groups (appendix S3) and was consistent with the NMA results. EmCS was worse, with the difference being the biggest observed of any comparisons in this paper $(\mathrm{p}<0.001)$. 
Three studies found a significant difference in PTSD symptoms between EmCS and ElCS, and another three found a difference which was not significant .

A meta-analysis of three studies showed a small-to-medium difference between women who had EmCS and women who had ElCS (ES=0.36) (appendix S4), consistent with the NMA. EmCS was associated with a higher score of PTSD symptoms, a statistically significant difference $(\mathrm{p}<0.001)$.

With respect to the qualitative studies, Tham et al. interviewed 84 women who had an EmCS, 42 of whom had gone on to develop symptoms of PTSD. They found that women who developed PTSD symptoms after an EmCS were more likely to feel unsupported by staff and not feel involved in the decision to proceed to a caesarean section than those who did not develop PTSD.

\section{Elective caesarean section}

As stated above, three of the quantitative studies which compared ElCS and EmCS found a significantly lower level of PTSD symptoms in the former . Of note is that Nyberg et al. found that the specialist midwives they interviewed did not consider an ElCS to be a better mode of birth for women with PTSD from previous traumatic births, as those who proceeded with an ElCS in subsequent pregnancies felt dissatisfied with their experience. The midwives considered that avoiding another vaginal birth left the women's fears of childbirth unresolved.

\section{Instrumental vaginal delivery}

A meta-analysis of two studies found that IVD was associated with a higher PTSD score than SVD (appendix S5), again consistent with the NMA findings. The small-to-medium difference $(\mathrm{ES}=0.38)$ was strongly statistically significant $(\mathrm{p}<0.001)$.

Two studies subdivided instrumental vaginal deliveries into forceps and ventouse deliveries . Creedy et al. found an association between forceps and ventouse deliveries and PTSD symptoms. In contrast to this, Lyons found no significant relationship between PTSD symptoms and mode of delivery .

Five of the other studies combined instrumental vaginal births into one variable. Furuta et al. found PTSD symptoms were more common with IVD than SVD. Dekel et al. found greater PTSD symptoms in IVD than in SVD and their separate category of natural VD (without anaesthesia). Ryding et al. did not directly compare IVD and SVD, but found no significant difference between PTSD symptoms in those who had IVD and those who had EmCS, which they found to be more related to PTSD than both ElCS and SVD. Cohen et al. found no significant differences between IVD, SVD and CS, Polachek et al. did not find an association with any mode of birth and PTSD and Vossbeck-Elsebuschet al. found no statistically significant association between IVD and PTSD.

\section{Discussion}

\section{MAIN FINDINGS}

Although the studies identified by the quantitative search provided varied results, eight out of the 12 studies found mode of birth to be significantly associated with maternal development of symptoms of PTSD postnatally. Meta-analysis showed that PTSD symptoms were worse in women who had CS compared to those who had VD $(p=0.005)$. Symptoms were also worse in women who had EmCS than in those who had either SVD $(\mathrm{p}<0.001)$ or ElCS $(\mathrm{p}<0.001)$. The significant difference between EmCS and ElCS may have confounded the first analysis which pooled these two CS groups. Evidence showed that women who had CS births worried more about the safety of their baby and felt less satisfied overall with their birthing experience, a finding which reflects the literature indicating that women may perceive CS as more traumatic than VD .

All of the midwives interviewed by Nyberg et al. reported being asked by women with postnatal PTSD for an ElCS in a subsequent pregnancy, but did not believe that this was the optimum mode of birth for this group of women. The other included qualitative study compared the experiences of women who did and did not develop symptoms of PTSD after an EmCS. Women who did not develop PTSD felt more supported 
by staff and more involved with the decision to proceed to a caesarean. This study suggests that although EmCS may be associated with an increased likelihood of postnatal PTSD, compassionate care and ensuring that women are involved in decision-making can mediate against this effect.

The importance of the impact of inadequate support from staff during labour and birth on women with PTSD supported findings from Nyberget al. This study reported that many women with postnatal PTSD later told specialist midwives that they felt a lack of support and control during the birth resulting in their PTSD . These findings provide some insight into how a perceived lack of support from labour ward staff could have a considerable detrimental effect on maternal mental health outcomes. NICE guidelines recommend that women are offered the opportunity to talk about their birth experiences at every postnatal contact, which may mitigate against this. No studies were found which evaluated the role of support from partners, families and peers as a potential mitigating factor against PTSD. This is an important avenue for future research.

\section{STRENGTHS AND LIMITATIONS}

This is the first systematic review and meta-analysis to combine information from small and medium sized studies, and present synthesised findings about the association of birth mode and maternal postnatal PTSD, reducing the uncertainty that is associated with each single study. However, there are several limitations. There was an issue with the inclusion criterion of "live, term, singleton births". Six of the included studies did not specify this within their paper, and although efforts were made to contact authors to verify this, only three replied to confirm their paper met this criterion. This left three studies included on a benefit of the doubt basis .

The meta-analysis compiled the most relevant clinical information, utilising robust statistical methods to synthesise the evidence on birthing methods and PTSD symptoms. A statistician (DG) performed both MA and NMA to utilise all direct and indirect information. A potential limitation with this was the assumption of equivalence in the measures used in the difference studies and the follow-up points. If these assumptions fail to hold then they may have introduced heterogeneity into the studies. A meta-analysis of SMDs assumes the populations of each study contain equivalent variation.

\section{CONCLUSION}

Although there was some variation in the studies, an overall conclusion can be made that mode of birth has an impact on PTSD in the postnatal period. Women who have emergency CS and instrumental VD might be at an increased risk, although it is important to note that women with all types of birth experience go on to develop PTSD, and the disorder is not limited to those who had a birth that would be deemed traumatic from a clinical perspective. Qualitative data indicated that although elective CS may not be associated with postnatal PTSD, they might have a negative impact on women with pre-existing postnatal PTSD. Support and involvement in decision-making from staff during labour may have a protective effect against women who experience emergency obstetric intervention, but more work must be done to confirm the above findings.

\section{Disclosure of Interests}

None to declare. ICMJE disclosure of interest forms are available as supporting information online.

\section{Contribution to Authorship}

D.B. and Y-S.C. formulated the idea for the systematic review. J.C. carried out the database searching, study selection, data extraction and quality appraisal, with Y-S.C. as a second reviewer. D.G. performed the statistical analysis and meta-analysis.

\section{Details of Ethics Approval}

As only data from published studies were used, ethical approval was not required.

\section{Funding}


No funding was received for this study.

\section{References}

Table 1

Summary of findings of quantitative search

\begin{tabular}{|c|c|c|c|c|c|c|c|}
\hline Study & $\begin{array}{l}\text { Intervention } \\
\text { type }\end{array}$ & $\begin{array}{l}\text { Study } \\
\text { sample }\end{array}$ & $\begin{array}{l}\text { Aims of } \\
\text { study }\end{array}$ & Methodology & $\begin{array}{l}\text { Outcome } \\
\text { measures }\end{array}$ & $\begin{array}{l}\text { Important } \\
\text { results }\end{array}$ & $\begin{array}{l}\text { Quality } \\
\text { appraisal }\end{array}$ \\
\hline $\begin{array}{l}\text { Cohen, } \\
2004\end{array}$ & $\begin{array}{l}\text { SVD11Spontan } \\
\text { Vaginal } \\
\text { Delivery, } \\
\text { IVD22Instrume } \\
\text { Vaginal } \\
\text { Delivery, } \\
\text { CS33Caesarean } \\
\text { Section }\end{array}$ & edus 240 & $\begin{array}{l}\text { Discover } \\
\text { the link } \\
\text { between } \\
\text { factors } \\
\text { making for } \\
\text { a difficult } \\
\text { birth and } \\
\text { postnatal } \\
\text { PTSD } \\
\text { symptoms. }\end{array}$ & $\begin{array}{l}\text { Longitudinal. } \\
\text { Question- } \\
\text { naire } \\
\text { (phone). }\end{array}$ & $\begin{array}{l}\text { Davidson } \\
\text { Trauma } \\
\text { Scale } \\
\text { (DTS) }\end{array}$ & $\begin{array}{l}\text { No } \\
\text { significant } \\
\text { difference } \\
\text { between } \\
\text { PTSD } \\
\text { symptoms } \\
\text { across } 3 \\
\text { modes of } \\
\text { birth } \\
\text { (Chi- } \\
\text { squared P } \\
\text { value } \\
0.838 \text { ). }\end{array}$ & $\begin{array}{l}\text { NOS: } \\
\text { Medium }\end{array}$ \\
\hline Creedy, 2000 & $\begin{array}{l}\text { SVD, } \\
\text { forceps, } \\
\text { vacuum, } \\
\text { ElCS44Elective } \\
\text { Caesarean } \\
\text { Section, } \\
\text { EmCS55Emerge } \\
\text { Caesarean } \\
\text { Section, }\end{array}$ & $\begin{array}{l}\mathrm{N}=592 \\
\text { ency }\end{array}$ & $\begin{array}{l}\text { Identify risk } \\
\text { factors for } \\
\text { psychologi- } \\
\text { cal distress } \\
\text { after } \\
\text { childbirth. }\end{array}$ & $\begin{array}{l}\text { Prospective } \\
\text { longitudinal. } \\
\text { Interview } \\
\text { (phone). }\end{array}$ & $\begin{array}{l}\text { Post- } \\
\text { traumatic } \\
\text { Stress } \\
\text { Symptoms } \\
\text { interview } \\
\text { (PSS) }\end{array}$ & $\begin{array}{l}\text { EmCS, } \\
\text { forceps and } \\
\text { vacuum } \\
\text { deliveries } \\
\text { associated } \\
\text { with PTSD } \\
\text { symptoms } \\
(\beta=0.196 \\
\mathrm{P}=0.0001, \\
\beta=0.173 \\
\mathrm{p}=0.0001 \\
\text { and } \beta=0.135 \\
\mathrm{p}=0.003) .\end{array}$ & $\begin{array}{l}\text { NOS: } \\
\text { Medium }\end{array}$ \\
\hline Dekel, 2019 & $\begin{array}{l}\text { NAVD 66No } \\
\text { Anaesthesia } \\
\text { Vaginal } \\
\text { Delivery, } \\
\text { SVD, IVD, } \\
\text { ElCS, EmCS }\end{array}$ & $\mathrm{N}=685$ & $\begin{array}{l}\text { Ascertain } \\
\text { whether } \\
\text { women who } \\
\text { undergo } \\
\text { different } \\
\text { mode of } \\
\text { deliveries } \\
\text { also differ in } \\
\text { regard to } \\
\text { their mental } \\
\text { health } \\
\text { postnatally. }\end{array}$ & $\begin{array}{l}\text { Longitudinal. } \\
\text { Question- } \\
\text { naire } \\
\text { (internet). }\end{array}$ & $\begin{array}{l}\text { PTSD } \\
\text { checklist for } \\
\text { DSM-5 } \\
\text { (PCL-5) }\end{array}$ & $\begin{array}{l}\text { PCL-5 score } \\
\text { EmCS }> \\
\text { ElCS }>\text { IVD } \\
>\text { SVD > } \\
\text { NAVD. } \\
\text { Delivery } \\
\text { mode } \\
\text { accounted } \\
\text { for } 13 \% \text { of } \\
\text { variance in } \\
\text { symptoms } \\
\text { severity } \\
(\text { Pillai's T= } \\
.13, \mathrm{~F}(36, \\
2700)= \\
2.48, \mathrm{p}< \\
.0001) .\end{array}$ & CEBM: $6 / 12$ \\
\hline
\end{tabular}




\begin{tabular}{|c|c|c|c|c|c|c|c|}
\hline Study & $\begin{array}{l}\text { Intervention } \\
\text { type }\end{array}$ & $\begin{array}{l}\text { Study } \\
\text { sample }\end{array}$ & $\begin{array}{l}\text { Aims of } \\
\text { study }\end{array}$ & Methodology & $\begin{array}{l}\text { Outcome } \\
\text { measures }\end{array}$ & $\begin{array}{l}\text { Important } \\
\text { results }\end{array}$ & $\begin{array}{l}\text { Quality } \\
\text { appraisal }\end{array}$ \\
\hline $\begin{array}{l}\text { Fairbrother, } \\
2007\end{array}$ & $\begin{array}{l}\text { VD77Vaginal } \\
\text { Delivery, CS }\end{array}$ & $\mathrm{N}=99$ & $\begin{array}{l}\text { Examine } \\
\text { psychologi- } \\
\text { cal and } \\
\text { obstetrical } \\
\text { risk factors } \\
\text { predicting } \\
\text { postnatal } \\
\text { PTSD } \\
\text { symptoms. }\end{array}$ & $\begin{array}{l}\text { Prospective } \\
\text { longitudinal. } \\
\text { Questionnaire. }\end{array}$ & $\begin{array}{l}\text { PTSD } \\
\text { Symptoms } \\
\text { Scale } \\
\text { Self-Report } \\
\text { (PSS-SR) }\end{array}$ & $\begin{array}{l}\text { Significant } \\
\text { association } \\
\text { between } \\
\text { mode of } \\
\text { birth (CS } \\
\text { versus VD) } \\
\text { and PTSD }\end{array}$ & $\begin{array}{l}\text { NOS: } \\
\text { Medium }\end{array}$ \\
\hline Feeley, 2017 & $\begin{array}{l}\text { VD, ElCS, } \\
\text { EmCS }\end{array}$ & $\mathrm{N}=298$ & $\begin{array}{l}\text { Investigating } \\
\text { PTSD } \\
\text { symptoms in } \\
2 \text { high-risk } \\
\text { groups (Low } \\
\text { birthweight } \\
\text { infant who } \\
\text { was } \\
\text { admitted to } \\
\text { a NICU, and } \\
\text { EmCS) and } \\
2 \text { low-risk } \\
\text { groups (VD } \\
\text { and ElCS). }\end{array}$ & $\begin{array}{l}\text { Longitudinal. } \\
\text { Question- } \\
\text { naire \& } \\
\text { interview } \\
\text { (visited at } \\
\text { home). }\end{array}$ & $\begin{array}{l}\text { Perinatal } \\
\text { PTSD Ques- } \\
\text { tionnaire } \\
\text { (PPQ) }\end{array}$ & $\begin{array}{l}\text { PPQ mean } \\
\text { score at } 5 \\
\text { weeks NICU } \\
>\text { EmCS > } \\
\text { VD > ElCS } \\
(\mathrm{P}=0.01) \text {. } \\
\text { No } \\
\text { significant } \\
\text { difference } \\
\text { between } \\
\text { PPQ scores } \\
\text { in clinical } \\
\text { range at } 5 \\
\text { weeks. } \\
\text { EmCS did } \\
\text { not have } \\
\text { significantly } \\
\text { greater } \\
\text { PTSD } \\
\text { symptoms } \\
\text { than ElCS } \\
\text { or VD. }\end{array}$ & $\begin{array}{l}\text { NOS: } \\
\text { Medium }\end{array}$ \\
\hline
\end{tabular}




\begin{tabular}{|c|c|c|c|c|c|c|c|}
\hline Study & $\begin{array}{l}\text { Intervention } \\
\text { type }\end{array}$ & $\begin{array}{l}\text { Study } \\
\text { sample }\end{array}$ & $\begin{array}{l}\text { Aims of } \\
\text { study }\end{array}$ & Methodology & $\begin{array}{c}\text { Outcome } \\
\text { measures }\end{array}$ & $\begin{array}{l}\text { Important } \\
\text { results }\end{array}$ & $\begin{array}{l}\text { Quality } \\
\text { appraisal }\end{array}$ \\
\hline $\begin{array}{l}\text { Furuta, } \\
2016\end{array}$ & $\begin{array}{l}\text { SVD, } \\
\text { IVD, } \\
\text { ElCS, } \\
\text { EmCS }\end{array}$ & $\mathrm{N}=1824$ & $\begin{array}{l}\text { Identify } \\
\text { risk } \\
\text { factors for } \\
\text { PTSD in } \\
\text { the } \\
\text { postnatal } \\
\text { period. }\end{array}$ & $\begin{array}{l}\text { Secondary } \\
\text { analysis of } \\
\text { cohort } \\
\text { study. }\end{array}$ & $\begin{array}{l}\text { Impact of } \\
\text { Event } \\
\text { Scale } \\
\text { (IES) }\end{array}$ & $\begin{array}{l}\text { PTSD } \\
\text { symptoms } \\
\text { more } \\
\text { common } \\
\text { in IVD (p } \\
=0.03 \text { and } \\
0.02 \text { for } \\
\text { symptoms } \\
\text { of } \\
\text { intrusion } \\
\text { and } \\
\text { avoidance, } \\
\text { respec- } \\
\text { tively) or } \\
\text { EmCS (p } \\
<0.001 \\
\text { for both } \\
\text { intrusion } \\
\text { and } \\
\text { avoidance) } \\
\text { compared } \\
\text { with SVD. }\end{array}$ & $\begin{array}{l}\text { NOS: } \\
\text { Medium }\end{array}$ \\
\hline $\begin{array}{l}\text { Lyons, } \\
1998\end{array}$ & $\begin{array}{l}\text { SVD, } \\
\text { forceps, } \\
\text { ventouse, } \\
\text { CS }\end{array}$ & $\mathrm{N}=42$ & $\begin{array}{l}\text { Investigate } \\
\text { symptoms } \\
\text { of PTSD } \\
\text { in a group } \\
\text { of } \\
\text { first-time } \\
\text { mothers. }\end{array}$ & $\begin{array}{l}\text { Longitudinal. } \\
\text { Question- } \\
\text { naire } \\
\text { (post). }\end{array}$ & IES & $\begin{array}{l}\text { Mode of } \\
\text { delivery } \\
\text { was not } \\
\text { related to } \\
\text { PTSD } \\
\text { symptoms } \\
\text { (Kruskal- } \\
\text { Wallis, } \\
\mathrm{H}(3)= \\
2.39, \mathrm{p}= \\
0.5) .\end{array}$ & $\begin{array}{l}\text { NOS: } \\
\text { Medium }\end{array}$ \\
\hline $\begin{array}{l}\text { Noyman- } \\
\text { Veksler, } \\
2015\end{array}$ & $\begin{array}{l}\text { SVD, } \\
\text { EmCS, } \\
\text { ElCS }\end{array}$ & $\mathrm{N}=142$ & $\begin{array}{l}\text { Investigate } \\
\text { protective } \\
\text { factors } \\
\text { against } \\
\text { PTSD } \\
\text { symptoms } \\
\text { after } \\
\text { EmCS. }\end{array}$ & $\begin{array}{l}\text { Longitudinal. } \\
\text { Questionnaire. }\end{array}$ & PDS & $\begin{array}{l}\text { No } \\
\text { significant } \\
\text { differences } \\
\text { were } \\
\text { found } \\
\text { between } \\
\text { the three } \\
\text { modes of } \\
\text { delivery. }\end{array}$ & $\begin{array}{l}\text { NOS: } \\
\text { Medium }\end{array}$ \\
\hline
\end{tabular}




\begin{tabular}{|c|c|c|c|c|c|c|c|}
\hline Study & $\begin{array}{l}\text { Intervention } \\
\text { type }\end{array}$ & $\begin{array}{l}\text { Study } \\
\text { sample }\end{array}$ & $\begin{array}{l}\text { Aims of } \\
\text { study }\end{array}$ & Methodology & $\begin{array}{l}\text { Outcome } \\
\text { measures }\end{array}$ & $\begin{array}{l}\text { Important } \\
\text { results }\end{array}$ & $\begin{array}{l}\text { Quality } \\
\text { appraisal }\end{array}$ \\
\hline $\begin{array}{l}\text { Polachek, } \\
2012\end{array}$ & $\begin{array}{l}\text { SVD, } \\
\text { IVD, } \\
\text { ElCS, } \\
\text { EmCS }\end{array}$ & $\mathrm{N}=102$ & $\begin{array}{l}\text { Examine } \\
\text { postnatal } \\
\text { PTSD in } \\
\text { women in } \\
\text { Israel and } \\
\text { examine } \\
\text { risk and } \\
\text { protective } \\
\text { factors. }\end{array}$ & $\begin{array}{l}\text { Longitudinal. } \\
\text { Questionnaire. }\end{array}$ & PDS & $\begin{array}{l}\text { No } \\
\text { significant } \\
\text { associa- } \\
\text { tion } \\
\text { between } \\
\text { mode of } \\
\text { birth and } \\
\text { PTSD. }\end{array}$ & $\begin{array}{l}\text { NOS: } \\
\text { Medium }\end{array}$ \\
\hline $\begin{array}{l}\text { Ryding, } \\
1998\end{array}$ & $\begin{array}{l}\text { SVD, } \\
\text { IVD, } \\
\text { ElCS, } \\
\text { EmCS }\end{array}$ & $\mathrm{N}=354$ & $\begin{array}{l}\text { Compare } \\
\text { psycholog- } \\
\text { ical } \\
\text { symptoms } \\
\text { in women } \\
\text { after } \\
\text { EmCS, } \\
\text { ElCS, IVD } \\
\text { and SVD. }\end{array}$ & $\begin{array}{l}\text { Longitudinal. } \\
\text { Question- } \\
\text { naire } \\
\text { (post). }\end{array}$ & IES & $\begin{array}{l}\text { EmCS }> \\
\text { ElCS }(\mathrm{P} \\
=0.01), \\
\text { EmCS }> \\
\text { SVD } \\
(\mathrm{P}<0.05) .\end{array}$ & $\begin{array}{l}\text { NOS: } \\
\text { Medium }\end{array}$ \\
\hline $\begin{array}{l}\text { Söderquist, } \\
2009\end{array}$ & $\begin{array}{l}\text { SVD, IVD, } \\
\text { ElCS, EmCS }\end{array}$ & $\mathrm{N}=508$ & $\begin{array}{l}\text { Find risk } \\
\text { factors in } \\
\text { pregnancy } \\
\text { for post- } \\
\text { traumatic } \\
\text { stress (PTS) } \\
\text { and } \\
\text { depression } 1 \\
\text { month after } \\
\text { childbirth. }\end{array}$ & $\begin{array}{l}\text { Longitudinal. } \\
\text { Questionnaire. }\end{array}$ & $\begin{array}{l}\text { Traumatic } \\
\text { Event Scale } \\
\text { (TES) }\end{array}$ & $\begin{array}{l}\text { PTSD } \\
\text { symptoms } \\
\text { related to } \\
\text { mode of } \\
\text { delivery } \\
(\mathrm{F}(1,432)= \\
4.9, \mathrm{P}= \\
0.002) . \\
\text { EmCS led to } \\
\text { more PTSD } \\
\text { symptoms } \\
\text { than SVD or } \\
\text { ElCS } \\
\text { (P=0.01; } \\
\mathrm{P}=0.03, \\
\text { Scheffé post } \\
\text { hoc test). }\end{array}$ & $\begin{array}{l}\text { NOS: } \\
\text { Medium }\end{array}$ \\
\hline
\end{tabular}




\begin{tabular}{|c|c|c|c|c|c|c|c|}
\hline Study & $\begin{array}{l}\text { Intervention } \\
\text { type }\end{array}$ & $\begin{array}{l}\text { Study } \\
\text { sample }\end{array}$ & $\begin{array}{l}\text { Aims of } \\
\text { study }\end{array}$ & Methodology & $\begin{array}{l}\text { Outcome } \\
\text { measures }\end{array}$ & $\begin{array}{l}\text { Important } \\
\text { results }\end{array}$ & $\begin{array}{l}\text { Quality } \\
\text { appraisal }\end{array}$ \\
\hline $\begin{array}{l}\text { Vossbeck- } \\
\text { Elsebusch, } \\
2014\end{array}$ & $\begin{array}{l}\text { SVD, IVD, } \\
\text { ElCS, } \\
\text { EmCS, } \\
2^{\circ} \mathrm{CS}^{7}\end{array}$ & $\mathrm{~N}=521$ & $\begin{array}{l}\text { Investigate } \\
\text { risk factors } \\
\text { for PTSD } \\
\text { outlined in } \\
\text { Ehlers and } \\
\text { Clark's } \\
(2000) \\
\text { model of } \\
\text { PTSD. }\end{array}$ & $\begin{array}{l}\text { Cross- } \\
\text { sectional. } \\
\text { Question- } \\
\text { naire } \\
\text { (online). }\end{array}$ & $\begin{array}{l}\text { PDS } \\
\text { (German } \\
\text { version) }\end{array}$ & $\begin{array}{l}\text { PDS scores } \\
\text { differed } \\
\text { depending } \\
\text { on mode of } \\
\text { birth, } \\
\mathrm{F}(4,219)= \\
7.07, \mathrm{p}< \\
0.001, \eta \mathrm{p}^{2}= \\
0.11 \\
\text { (univariate } \\
\text { ANOVA). } \\
\text { Post- } \\
\text { hoc Scheffé } \\
\text { tests showed } \\
\text { more } \\
\text { symptoms in } \\
\text { EmCS (M = } \\
16.17, \mathrm{SD}= \\
11.04, \mathrm{p} \\
=0.001) \\
\text { than SVD } \\
(\mathrm{M}=7.04, \\
\text { SD = 7.56). }\end{array}$ & CEBM: 5/12 \\
\hline
\end{tabular}




\begin{tabular}{|c|c|c|c|c|c|c|}
\hline Study & $\begin{array}{l}\text { Question } \\
\text { answered }\end{array}$ & $\begin{array}{l}\text { Study } \\
\text { sample }\end{array}$ & $\begin{array}{l}\text { Aims of } \\
\text { study }\end{array}$ & Methodology & $\begin{array}{l}\text { Important } \\
\text { results }\end{array}$ & $\begin{array}{l}\text { Quality } \\
\text { appraisal }\end{array}$ \\
\hline Nyberg, 2010 & $\begin{array}{l}\text { What are the } \\
\text { views of those } \\
\text { who support } \\
\text { women (i.e. } \\
\text { family and } \\
\text { close friends, } \\
\text { peer support } \\
\text { groups, } \\
\text { midwives and } \\
\text { other relevant } \\
\text { healthcare } \\
\text { staff) on } \\
\text { impact of } \\
\text { birth mode on } \\
\text { development } \\
\text { of PTSD? }\end{array}$ & $\begin{array}{l}\text { N=8 midwives } \\
\text { at specialist } \\
\text { clinic for } \\
\text { women with } \\
\text { PTSD after } \\
\text { birth }\end{array}$ & $\begin{array}{l}\text { Describe } \\
\text { specialist } \\
\text { midwives' } \\
\text { experiences of } \\
\text { working with } \\
\text { women with } \\
\text { postnatal } \\
\text { PTSD. }\end{array}$ & $\begin{array}{l}\text { Semi- } \\
\text { structured } \\
\text { interviews } \\
\text { analysed using } \\
\text { thematic } \\
\text { content } \\
\text { analysis. }\end{array}$ & $\begin{array}{l}\text { Midwives } \\
\text { reported a } \\
\text { large number } \\
\text { of women } \\
\text { requesting } \\
\text { ElCS after a } \\
\text { previous } \\
\text { traumatic } \\
\text { birth, but felt } \\
\text { that planning } \\
\text { a vaginal } \\
\text { delivery and } \\
\text { appropriately } \\
\text { supporting } \\
\text { women } \\
\text { throughout } \\
\text { helped women } \\
\text { confront their } \\
\text { past } \\
\text { experiences } \\
\text { and move on } \\
\text { from them. } \\
\text { Women who } \\
\text { did have ElCS } \\
\text { tended to feel } \\
\text { dissatisfied at } \\
\text { their choice. } \\
\text { Women felt } \\
\text { like midwives } \\
\text { were not } \\
\text { supportive and } \\
\text { did not listen } \\
\text { to them } \\
\text { properly and } \\
\text { this worsened } \\
\text { their } \\
\text { experience of } \\
\text { traumatic } \\
\text { birth. }\end{array}$ & CASP: $9 / 10$ \\
\hline
\end{tabular}




\begin{tabular}{|c|c|c|c|c|c|c|}
\hline Study & $\begin{array}{l}\text { Question } \\
\text { answered }\end{array}$ & $\begin{array}{l}\text { Study } \\
\text { sample }\end{array}$ & $\begin{array}{l}\text { Aims of } \\
\text { study }\end{array}$ & Methodology & $\begin{array}{l}\text { Important } \\
\text { results }\end{array}$ & $\begin{array}{l}\text { Quality } \\
\text { appraisal }\end{array}$ \\
\hline Tham, 2010 & $\begin{array}{l}\text { How do } \\
\text { women who } \\
\text { have PTSD } \\
\text { perceive the } \\
\text { impact of } \\
\text { social/peer } \\
\text { support on } \\
\text { their mental } \\
\text { health } \\
\text { outcomes? }\end{array}$ & $\begin{array}{l}\mathrm{N}=84 \\
\text { women who } \\
\text { had EmCS } \\
\text { and } \\
\text { developed } \\
\text { PTSS } \\
\text { (n=42) or } \\
\text { did not } \\
\text { develop } \\
\text { PTSS } \\
(\mathrm{n}=42)\end{array}$ & $\begin{array}{l}\text { Compare the } \\
\text { experiences } \\
\text { of women } \\
\text { who } \\
\text { underwent } \\
\text { EmCS and } \\
\text { the } \\
\text { differences } \\
\text { between } \\
\text { those who } \\
\text { did and did } \\
\text { not develop } \\
\text { PTSD. }\end{array}$ & $\begin{array}{l}\text { Telephone } \\
\text { interview } 6 \\
\text { months after } \\
\text { birth } \\
\text { recorded by } \\
\text { hand and } \\
\text { analysed by } \\
\text { content } \\
\text { analysis. }\end{array}$ & $\begin{array}{l}\text { Women with } \\
\text { PTSD were } \\
\text { more likely } \\
\text { to report: } \\
\text { midwives } \\
\text { seeming } \\
\text { nervous, } \\
\text { midwives } \\
\text { being unsup- } \\
\text { ported, not } \\
\text { feeling } \\
\text { involved in } \\
\text { decisions } \\
\text { about their } \\
\text { treatment } \\
\text { and feeling } \\
\text { like the baby } \\
\text { would die. }\end{array}$ & CASP: $9 / 10$ \\
\hline
\end{tabular}

Table 2

Summary of findings of qualitative search

\section{Hosted file}

Figure 1- quantitative PRISMA.docx available at https://authorea.com/users/338025/articles/ 463990-mode-of-birth-and-development-of-maternal-postnatal-post-traumatic-stressdisorder-a-mixed-methods-systematic-review-and-meta-analysis

\section{Hosted file}

Figure 2- qualitative PRISMA.docx available at https://authorea.com/users/338025/articles/ 463990-mode-of-birth-and-development-of-maternal-postnatal-post-traumatic-stressdisorder-a-mixed-methods-systematic-review-and-meta-analysis

\section{Hosted file}

Figure 3- Meta-Analysis CS vs VD.docx available at https://authorea.com/users/338025/ articles/463990-mode-of-birth-and-development-of-maternal-postnatal-post-traumaticstress-disorder-a-mixed-methods-systematic-review-and-meta-analysis 